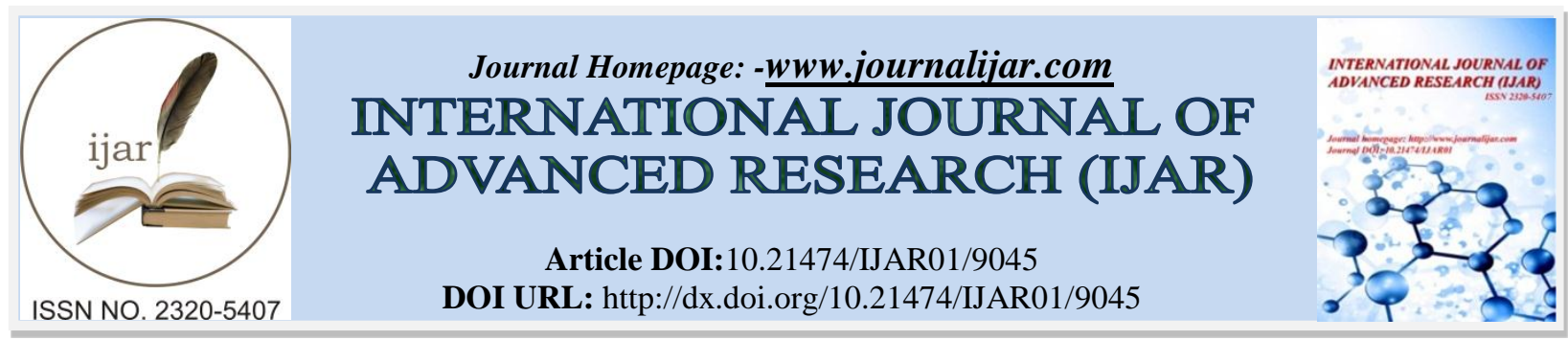

RESEARCH ARTICLE

\title{
SOME FEATURES OF EXISTENTIAL SENTENCES IN LANGUAGES BELONGING TO DIFFERENT
} LANGUAGE SYSTEMS.

Shalala Mammadova.

Azerbaijan State Pedagogical University (ASPU) Dissertationist of the Chair of General Linguistics,Azerbaijan University of Languages.

\section{Manuscript Info}

..........................

Manuscript History

Received: 12 March 2019

Final Accepted: 14 April 2019

Published: May 2019

Key words:-

existence, to have, to be, adverbial modifier of time and place, word order.

\section{Abstract}

The article deals with the main features of existential sentences in English, Azerbaijani and Russian languages. The author makes such an inference that the existential sentences are of universal nature from semantic point of view. The article mentions the specific features inherent to existential sentences. Taking into account that the existential sentences in English and Russian have been studied in some extent, the author has focused attention mostly on the existential sentences in the Azerbaijani language. The author thinks that the existential sentences have not been the object of a separate study. Some issues here are approached from the point of view of the word order, some others are approached from the point of view of nominative sentences. The verbs olmaq and var play an important role in the formation of existential sentences in Azerbaijani. According to the author, the studied issue acquires a certain importance from the point of view of general and typologial linguistics and from the point of view of teaching foreign languages.As is known Engilish and Russian belong to Indo-European language family ,but Azerbaijani - to Turkic languages.That's why there exists a great difference in the use of word order. English and Russian have the following word order : SPO ,but Azerbaijani SOP. This difference is also observed in existential sentences. In Azerbaijani the verbs "olmaq" and "var" are usually used at the end of the sentence. Generally, existential sentences occupy a special place in the typology of simple sentences irrespective of the grammatical structure of the given languages.

Copy Right, IJAR, 2019,. All rights reserved.

\section{Introduction:-}

The living and lifeless beings, which surround us, retain their existence within the frames of a certain time and space in any case. Otherwise, it is impossible to speak of the existence of that thing. As it is known, language appears to be the mutual reflection of relations within the frames natural relations among the things and events. In other words, language fulfills an important function as the expression of reality. One of such functions is to show the existence of things and phenomena within the frames of a certain space and time. As an indicator of the existence in a language a special type of sentence is used in conformity with the grammatical structure of each language. The sentences of this type are called "existential sentences" in linguistics. The analysis of theoretical literature shows that the study of

Corresponding Author:-Shalala Mammadova.

Address:-Azerbaijan State Pedagogical University (ASPU) Dissertationist of the Chair of General Linguistics, Azerbaijan University of Languages. 
existential sentences are mainly connected with to be - есть - var, to have - иметь - olmaq and other verbs expressing existence.

hen speaking about the sentences expressing existence, first of all, it is necessary to proceed from the sentences, which have a special grammatical structure in the English language: There is a dog in the yard. The sentences of this type occupy a special place in the syntax of modern English due to their frequency. Before disclosing the structuralsemantic features of sentences with the said structure, it is necessary to shed some light on the history of the study of sentences expressing existence:

In his time O. Jespersen noted that A tailor was once living in a small house (Bir dəfə bir dərzi balaca bir yerdə yaşayırdı) as a rule is used in the form of Once upon a time there was a tailor (Biri var idi, biri yox, bir dərzi var idi). O. Jespersen called existential sentences those ones, which indicate that an article or thing exists, in a certain space. It is necessary to note that $\mathrm{O}$. Jespersen appealed to many language materials and concluded that the existential sentences of these types are universal in nature (Есперсен,1958,pp.175-177).

Charles Bally also exposed certain views concerning the existential sentences. He noted that the history of existence is directly connected with the notion of space: il y a un Dien (Allah var); lesmedecins sont la pour les maladies (Burada həkimlər xəstələr üçün mövcuddurlar). It becomes evident from the examples and explanations demonstrated by him that the existential sentences are of universal nature from semantic point of view (Bally,1955,p.90).

J. Lyons discloses different views about the existential sentences. Demonstrating the sentence There are lions in Africa, he notes that in that sentence the verb to be can be easily replaced by the verb to exist. In such sentences one may speak of real existential sentences (Layonz, 1978, p.413).

We encounter different views about the existential sentences in the Russian linguistics, too. S.D. Katsnelson notes that such sentences convey general information about the events, which take place in the human life. Thus, they form the basis of the information to be conveyed (Katsnelson, 1972, p.66): У него большое горе.

The ideas expressed by B. İsmayllov about the existential sentences acquire certain importance for other languages, too. According to him, the existential sentences answer like the following interrogative sentences as "Bu yerdə nə var? Nə hadisə baş verib? Nə olub"? etc. In such sentences confirmation or negation of the predicate attaches existential sense to the sentence and this attaches the attention more (Ismayllov, 2008, p.234).

There is an increasing interest in the study of existential sentences. From this point of view we should like to mention S.P. Anokhina's dissertation for doctoral degree particularly. It has been devoted to "Existential and possessive sentences in Germanic languages (structural-semantic and functional-pragmatic aspects"). In order to penetrate into the depth of the essence of the issue the materials of several Germanic languages have been subjected to investigation. Concretely, German es gibt, which corresponds the Russian verbs быть and иметь, there is (English), der er (Danish), det finns/finns, där är (Swedish), par er, par er til, er til (Icelandic) become the object of the her study (Anokhina ,1995, p.2). Basing on the facts of several languages, S. P. Anokhina comes to such a conclusion that the existential sentences are of universal nature from semantic point of view. She notes that the existence of an object, its location somewhere finds its reflection not only in the thinking of man, but also in different models of sentences of different languages (Anokhina ,1995, p.13).

It becomes clear from the afore-said that despite the differences in grammatical structures existential sentences find their reflection in different sentence models. Naturally, here we are interested in existential sentences existing in English, Azerbaijani and Russian.

Now let us have a glance at the history of the study of the existential sentences in the Russian language. In comparison with the study of the history of existential sentences in English and other Germanic languages, the history of this issue in the Russian linguistics is not so long. Only since the 70s-80s of the last century the existential sentences attracted the attention of the scholars.

The analysis of the theoretical literature shows that the sentences, which denote existence, were studied in a systemic form by N. D. Arutyunova in some degree in her book "Предложение и его смысл, логико-семантические проблемы”. In this book she devoted a whole chapter to existential sentences in Modern Russian (Arutyunova, 1976, 
pp.229-284). It is necessary to stress such a point that this part of the book forms the basis of all the studies written about the existential sentences. Not only the studies concerning the existential sentences in the Russian language, but all the studies on this problem in other languages are also based on the studies conducted by ND. Arutyunova.

It becomes clear from the explanation given above that the existential sentences in English and Russian have been studied in some degree, the existential sentences in the Azerbaijani language have never been the object of separate studies. It is also necessary to point out that O. Musayev is the first scholar in the linguistics of Azerbaijan, who gives information about the existential sentences. He mentions the following points, which differ the existential sentences from other types of sentences:

1. Existential sentences denote a special notion of existence.

2. The nouns in existential sentences are indefinite from grammatical point of view

3. Proper nouns are not used in such sentences.

4. As a rule, the subjects of these sentences are in the third person.( O.Musayev,1961, p.11)

The view of O. Musayev concerning the word order in existential sentences in Azerbaijani differs from other existing views specifically. This is the object of a separate study.

The view of O. Musayev concerning the existential sentences in Azerbaijani acquires certain importance. He notes that the sentences, which begin with adverbial modifiers of time and place, express a special notion of existence. He notes that the Azerbaijani sentences, which begin with the adverbial modifiers of time and place, express a special type of existence (Musayev, 1961, p.18).

1. Təpənin başında bir qalaça var (Azərbaycan nağılları, 82).

2. Günlərin bir günündə bir padişah var idi (Azərbaycan nağılları, 141).

Speaking about the mentioned type of sentences, O. Musayev approaches the problem only from the point of view of word order. He does not mention other features of existential sentences and they were not the goal of his study.

Now let us pay attention to the existential sentences in Azerbaijani and their use. It is necessary to note that the existential sentences in Azerbaijani are explained as nominative sentences. In the monograph "Müasir Azərbaycan dili. Sintaksis" (Modern Azerbaijani Language. Syntax) many of the sentences demonstrated there are called nominative sentences are the sentences, which are directly connected with our study. For example:

Sağ tərəfdə böyük və əzəmətli bir öküz heykəli.

Rəf üstündə istəkan, nəlbəki, qəndqab1, piyalə, çaynik və qeyri (Abdullayev, 1972, pp.251-252).

As it is obvious, in sentences of this type the dynamism of the secondary members of sentences is weak; they remind more the components of word combinations than the members of sentences.

We think that the views of Q. Kazımov, concerning the existential sentences, are interesting and catch the attention. It is also true that he speaks about them in the part of his studies devoted to nominative sentences. He notes that the nominative sentences are also extended with determinant adverbial modifiers of place (Veysəlli et.al., 2014, p.334). Q. Kazımov shows that the determinant is not a new member of the sentence. Determinant refers to the whole sentence and is connected with the content of the whole sentences. Determinant in Lain means determinans. It means determinant, clarifier. Thus, determinant is a word, or free word combination, which extends the shape of the sentence. As a rule, determinants are used at the beginning of sentences:Çöldə bir meydança. Bir tərəfdə dəyə.

Dəyənin qabağında çay. Sol tərəfdə telefon butkası, sağda ağac və skamya (Veysally et .al., 2014, p.334).

Undoubtedly, in the demonstrated sentences we can easily use the word var. But as they are demonstrated as nominative sentences, the word var is not used in them. The most important for our research is the word, or word combination called determinant by Q. Kazımov, such words and word combinations as sağda, bir tərəfdə, dəyənin qabağında, çöldə function in Azerbaijani the existential sentences as the localizator (adverbial modifier of place). For example:

1. Bəndin yanında bir dağ var idi.(Koroğlu, 167)

2. Bunların evlərinin qabağında bir bağçaları vardı (Azərbaycan nağılları, 93). 
In the demonstrated examples the word combinations bəndin yanında, bunların evlərinin qabağında are localizators, the word combinations bir dağ and bir baxça denote the existing thing, but the word var denotes the existence of that thing. Thus, in Modern Azerbaijani the simple form of the existential sentence is in the form demonstrated above. In comparision with English Azerbaijani existential sentences emerge like the following:

Həyətdo bir it var. There is a dog in the yard .

Though there are differences in the word order they are identical in both languages from semantic point of view. A thing or an article existing in both languages may be used with a noun or pronoun in indefinite category:

Otaqda kimsə var. - There is somebody in the room.

There is the same appropriateness in the use of the indefinite pronoun in both sentences.

Another type of the existential sentence in Azerbaijani is the one in which the word "var" is used with a noun in possessive case . For instance:

1.Mənim iki atım var (Azərbaycan nağılları, 135).

1. Padişahın üç oğlu var idi (Azərbaycan nağılları, 111).

As we see, the relation of possession in the first sentence finds its expression twice: a) by the possessive suffix - 1m in the word atim; b) by the the word "var". The sentences of this kind are translated into English like this: I have two horses. In the second sentence we have the same situation: a) the use of the suffix of the possessive case - in in the word padşahın; b) the word "var". This sentence is also translated into English in the same way: The king had three sons. It is necessary to keep in mind that the English sentences like I have a book are literally translated into Azerbaijani like this: Mən kitaba malikəm. As it is known, as there are no sentences in Azerbaijani having such a structure, therefore, the language learners (particularly in the initial stage of learning) mistranslate such sentences under the impression of the

Azerbaijani language: My have a book. My friend's has a book. Just because of this it is necessary to pay a particular attention to this issue in the process of teaching.

It is impossible to enumerate all the investigations devoted to existential sentences and there is no need for it.

The analysis of theoretical literature shows that the number of the languages with different grammatical structures, in which the existential sentences are sudied, is growing. For instance, L. McNally characterizes the existential sentences in English according to their structural peculiarities by proceeding from many language materials like the following: From syntactacal point of view the existential sentences have five features inherent to them (Louise McNally, pp1-2):

1. the formal subject of the existential sentence is expressed with the word "there" (expletive subject), but there are languages in which there are no such subjects;

2. the predicate may be expressed with different verbs expressing existence depending on the grammatical structure of the language;

3. in the majority of existential sentences the presence of pilot nominal is one of the main conditions;

4. in a number of ccases pilot nominal is used with deterniants (a boy playing in the yard);

5. depending on the grammatical structure of the language the space, where the thing is (localizator), may be expressed with different adverbial modifiers of place and time.

The above-mentioned features may be inherent to the majority of languages, irrespective of the grammatical structures of languages.

Two things catch the attention when dealing with the semantic and discoursive features of existential sentences:

1. the existential sentences convey new information about the existing thing and include it to the speech situation;

2. the existential sentences convey new information about the existing thing, of which is spoken and which is known to the listener.

These mentioned features are inherent probably to the majority of languages. Of course, depending on the grammatical structures of languages, the existential sentences may have different forms.

In modern English the existential sentences differ from other types of sentences according to their structure, and it is not accidental. The sentences like "There is a dog in the yard" emerged and developed in Old English and have retained their specific features up to the present time (Poltavtseva, 1958, p.30).

Unlike the English existential sentences, those existing in Russian and Azerbaijani in many cases begin with adverbial modifiers of time and place: "Во дворе собака", "Нәуәtdə it var". 
The verbs of existence used in existential sentences have always attracted the attention of linguists. The studies conducted on the materials of different languages show that in the majority of them "olmaq", "var" (to be, to have, быть, есть, иметь) are used. Though these verbs have been studied (Benvenist ,1974 ,pp.203- 224; Kuznetsov ,1977,pp.68-100; Russkie bitiynie qlaqol1 ,1989 ,pp.5-171; Yanko , 2000, pp.198-211) in different languages, in the Azerbaijani linguistics the verbs "olmaq", and "var", which semantically denote existence, have remained outside of attention. Here our main goal is to disclose the role of these verbs in the formation of existential sentences.

The inference of Q. Kazimov concerning the verb "olmaq" is very important for our study. According to him, when "olmaq" is used as an independent verb has two meanings: a) the verb "ol" is used in the meaning of "yaşamaq" (to live): Onlar yaxınlıqdakı meşənin ətəyində olurlar; b) the verb "ol” denotes the existence of a certain thing.

Q. Kazımov notes that the verb "ol" combines with nouns and form compound verbs: dost olmaq, heyran olmaq, dilxor olmaq, etc. (Veysally, 2014, p.199)

One can infer from the above said that the verb "ol" in Modern Azerbaijani is widely used in the meanings of mövcud olmaq, vaqe olmaq.

We should like to add to the said that in his article Q. Н. Bayramov "K вопросу о связочных глаголах в азербайджанском языке (в сопоставлении с английским) (On the link verbs in Azerbaijani (in comparison with those of English) speaks about the semantic variants of "olmaq" as a main verb, he makes such an inference that "olmaq" denotes that something, some quality takes place, some event happens or takes place, something changes. As an example he demonstrates such an example:

Hava qaranlıq oldu (Bayramov ,1977, p.68).

From the analysis conducted above it becomes clear that the verb "olmaq" plays the role of "to be" in English, "быть" in Russian functions as one of the factors in the formation of existential sentences.

"Azerbaijani-English Dictionary" mentions six meanings of the verb "olmaq"

(Azərbaycanca-ingiliscə lüğət ,1998, p.445)

Let us have view to different meanings of "olmaq" in the examples chosen by us:

\section{Olmaq as a notional verb:}

Sən ol mənim bacım, mən də olum sənin qardaşın (Azərbaycan nağılları, 28).

II. The verb olmaq shows the change of the state of a thing:

1.Bir də gördü üç göyərçin gəlib süfrənin qırağına, donların çıxarıb üç q1z oldular ki, vallah yemə, içmə bunların xəddi-xalına, gül camalına tamaşa elə(Azərbaycan nağılları, 41).

2.A kişi, bu qoyun kimindi, indi də camaat deyəcək Bəxtiyar kişi ağsaqqal çağında gedib xalxa çoban olub (Azərbaycan nağılları, 72).

3. Yuxumu çobana açıb, bütün sürüsünü, hətta itini, eşşəyinəcək aldı. Adların da dəyişib - çoban oldu, Bəxtiyar, kişi də oldu Məlik Məmməd (Azərbaycan nağılları, 72).

In the first sentence the verb olmaq expresses such a sense that the doves change the colour of their feathers and resemble young ladies, in the second sentence it says how a man has become shepherd not knowing what kind of activity it is, in the third sentence it shows that the names of both men have changed.

\section{The verb olmaq shows that an action takes place:}

1. Vali bir dəstə hökumət məmurları ilə orada hazır oldu (Y.V.Çəmənzəminli, s.291).

2. Bağışlayasan, qırx il deyil, müəllimliyə başladığım iyirmi səkkiz, ya iyirmi doqquz il olar (Y.V.Çəmənzəminli, s.277).

3. Lakin hələ kimsə nə olacağıni bilmirdi, çünki müəssisə sahibi orada yox idi(Y.V.Çəmənzəminli, s.237).

In these examples the verb olmaq is used for describing an action, which is taking place, or for describing an action which will take place.

IV. The verb olmaq shows that an action has(had)happened:

1.Avtomobil onları sürətlə apararkən birdən durdu. Hər kəs bir-birinin üzünə baxd1.-Nə oldu? - deyə soruşdu (Y.V.Çəmənzəminli, s.282). 
3. Ayköpə k q1zı! Bəs bulaqda göstərdiyin q1z necə oldu? Bu deyil! Bu deyil!... deyib qışqırdı (Y.V.Çəmənzəminli, s.30).

In the demonstrated examples the verb olmaq expresses an information about something that had happened.

V.The verb olmaq is used in many combinations in the meaning of to have, to possess:

1.Bir neçə aydan, gündən sonra arvadın bir oğlu oldu (Azərbaycan nağılları,160).

2.Üç gün sonra qayınanaya ayrıca bir otaq təxsis olundu (verildi): ümumi yol $\neg$ Onu bilirəm ki, behiştlik atan güclə yadımdadır. Qırmızı qurşağı vardı, özünün də əlində uzun təsbehi olardı (Y.V.Çəmənzəminli, s.277).

Though in all the three sentences the first components consisted of words having different meanings, the whole word combination shows that somebody possesses something. In the first sentence the woman has one child, in the second one the mother-in-law has a separate room and finally, the third sentence speaks that his father had beads made of grapes. The noted things taken from the pieces of texts show themselves conspicuously.

VI .In combination with other words having different meanings the verb olmaq means the exposure of something or its absence.

1. Bunu kimin üçün aparırsan?

Burada bir əjdaha peyda olubdur, suyun başını kəsib, kimsəyi su aparmağa qoymayır (Azərbaycan nağılları, 113).

2. Sübh olanda çıxıb görürlər ki, şəhərin kənarında qəribə bir imarət zahir olub. Hamı ona təəccüb edir (Azərbaycan nağılları, 187).

3. Bir gün bəy yox oldu. On gün sonra dəniz kənarında Zülfüqarla görüşdü (Y.V.Çəmənzəminli, s.268)..

The first sentence speaks of the presence of the monster, the second sentence of the existence of the building, the third one of the loss of the bride-groom.

Now let us have a look at the meanings of var. This verb has two meanings:

1. The word var shows that someting is exising somewhere, or someone is somewhere: There is a boy in the room. Otaqda bir oğlan var.

2. Var in the second meaning means to have and to exist: Mənim bir qardaşım var. - I have a brother. Marsda həyat varmı? - Does life exist on Mars?

In many cases the combination biri vardı, biri yoxdu is used as the beginning of texts in fairy tales.. Biri vard1, biri yoxdu bir kişi vardı. Once upon a time there was(there lived) a man.(Azərbaycan nağılları, 71).

At first sight the word var is very simple, but the variants of meanings, which they express, are very complicated. To shed light on this issue we were obliged to appeal to the problems mentioned in the article "Бытование и обладание: конструкции с глаголом быть“(Existence and possession: constructions with the verb быть - olmaq) by T.E.Yanko, who attempted to define the logical-semantic types of the verb есть. The meanings expressed in sentences with the verb var correspond to the meanings expressed by the word есть in Russian. Proceeding from the meanings expressed by the Russian verb есть, T.E.Yanko shows its following meanings (Yanko, 2000, pp.201-203): The verb var also can express the same meanings.

1. Utilitarian есть-var

2. Antonymic есть-var

3. Medical есть-var

4. In introductory sentences used beginning with есть-var

5. In the lexicon of police beginning with есть-var

6. When есть-var show the source of something

7. When есть-var show that something exists in the composition of something. Now it is necessary to stop on all of them separately:

I.At first let us pay attention to the lexical meaning of the word utilitar. The Russian-Azerbaijani Dictionary provides the following meanings for utilitarizm and utilitarist: a) an attempt of seeking profit, income from everything; b) self-interested, selfish, one who tries to profit from everything. Thus, when we say utilitar var, we mean that someone possesses, owns some wealth. Undoubtedly, nouns with different meanings may be used in this model. Not all the nouns may be utilitarian in nature.

1. Onda atamın çoxlu qaramalı var, naxırçı ola bilərsənmi? (Azərbaycan nağılları, 37) 
2. Ay baqqal, bir tay corabım var, nə qədər kişmiş verərsən, verim (Azərbaycan nağılları, 37).

3. Kişinin balaca bir oğlu var idi (Azərbaycan nağılları, 31).

4. Məhəmməd, mənim iki atım var (Azərbaycan nağılları, 135).4.

Analysis of language facts shows that utilitar var has much more usage opportunities. Here it is impossible to conduct a concrete systematization.

II. Antonymic var. It is necessary to note that the objectively existing parts of the body are not used with var in their real meanings. For instance, we never say that mənim ciyərim (böyrəyim, qaşım, gözüm, qulağım) var. But in the following cases the members of the body can be used with var. For instance, Onun əli-ayağı var, qoy işləsin və özünə çörək qazansın. Sənin gözün var, oxu hər şeyi öyrən. At the same time, when we characterize the parts of the body, the word var is again used: Onun ağ saçları var. Onun göy gözləri var. Uşağın qıvrım saçı var. Onun bir böyrəyi var (Qəza nəticəsində bir böyrəyini itirib)

III. Medical var. In medical var its use is directly connected with the diseases of people:. O, öskürür. Onun soyuq dəyməsi var. Deyəsən onun hərarəti var. O, özünü çox narahat hiss edir. Onun ciddi bir xəstəliyi var. Bu, nevroz xəstəliyidir. Onun sol qıçında yel xəstəliyi var

IV.Var in the introductory sentence. Var has broad text-creating opportunities. It functions as the introductory sentence of the text. For instance: Bu çobanın bir tulası var. Nə qədər eləyirəm, çobanın qoyunlarına yaxın durum, tulanın qorxusundan heç bir iş görə bilmirəm (Azərbaycan nağılları, 175). In this extract of the text the existence of a setter created conditions for the birth of the next sentence. The first sentence is the cause, the second one - its consecquence.

V.Var in the lexicon of police. In this model two variants are possible: a) Certain signs of the criminal are shown. For example: Onun sağ gözünün altında dərin çapıx var. Cinayətkarın ağ saçları var; b) Öldürülən kişinin bədənində çoxlu bıçaq yaraları var. Öldürülən kişinin boğazında əl izləri var.

VI.Var as an indicator of the source of the thing. For instance: Göyçayda çoxlu nar növləri var. Đgər İsveçrədə kənddə kenquru gəzirsə, onda yaxınlıqda heyvanxana var.

VII.Var shows that there is something in the content of something. For example: Salatda çoxlu mayonez var. As it is seen from the examples, var plays an important role in the formation of existential sentences because of its meaning and the moments of its usage.

To summarize all the said, it is possible to make the following inferences:

The existential sentences differ from other types of narrative sentences with their specific features. Such sentences are used to show the existence or non-existence of things within the frames of a concrete time and space. From semantic point of view existential sentences are of universal nature. Irrespective of the grammatical structure of the language, the notion of existence finds its expression in this or other form. Existential sentences play an important role in transmission of information in the flow of speech. The speaker conveys information on something in order to catch the attention of the listener. That information forms the starting point of the news to be conveyed. As a result of it, the existential sentences function as introductory sentences. Mainly the verbs to be, to have, var, есть, иметь, olmaq play an important role in the formation of existential sentences in English, Azerbaijani and Russian languages. The formation of existential sentences are mainly based on the background knowledge of the speaker and listener on reality. It is necessary to pay a special attention to two issues particularly existing in the sense of existential sentences: a) in what space a thing exists; b) when something takes place.

\section{References:-}

1. Azərbaycanca-ingiliscə lüğət. (1998)Azərbaycan Dövlət Dillər İnstitutu. Bakı.

2. Abdullayev O.Z., Seyidov Y.M., Həsənov A.Q. (1972) ,Müasir Azərbaycan dili. Sintaksis, IV hissə. Bak1 "Maarif" nəşriyyatı,.

3. İsmayılov B.B. (2008), Fransız dilinin aktual sintaksisi və onun tədrisi problemləri. Bak1, "Nurlan",.

4. Veysəlli F.Y., Kazımov Q.Ş., Kazımov İ.B., Məmmədov A.Y., (2014),Azərbaycan dilinin funksional qrammatikası: sintaqmatika, söz birləşməsi və sadə cümlə sintaksisi, III cild. Bakı "Prestige çap evi".

5. Louise McNally. Existential sentences.istore.org 
6. Анохина С.П. (1995),Бытийные и посессивные предложения в германских языках (структурносемантический и фукнционально-прагматический аспект). Автореф. дисс. ... доктора филол. наук. СанктПетербург,.

7. Арутюнова Н.Д. (1976) ,Предложение и его смысл. Логико-семантические проблемы. Москва, Изд-во "Наука".

8. Байрамов Г.Г.( 1977),К вопросу о связочных глаголах в азербайджанском языке (в сопоставлении с английском) // Azərbaycan SSR Ali və Orta İxtisas Təhsili Nazirliyi. №1.

9. Балли Ш. (1955),Общая лингвистика и впросы французского языка. Перевод с третьего французского издания Е.В. и Т.В.Вентцель. Изв-во иностранной литературы. Москва,.

10.Бенвенист Э. (1974),Глаголы “быть” и “иметь” и их функции в языке. В кн.: Общая лингвистика. Перевод с французского. Москва Изд-во “Прогресс",.

11.Есперсен О.( 1958),Философия грамматики. Перевод с английского В.В.Пассека и С.П. Сафроновой. Издво Иностранной литературы. Москва,

12.Кацнельсон С.Д. (1972) ,Типология языка и речевое мышление. Изд-во “Наука” Ленинградское отделение. Ленинград,.

13.Кузнецов А.М. (1977),Глагол “to be” и его лексико-грамматические эквиваленты в современном английском языке. В кн.: Категории бытия и обладания в языке. Москва, Изд-во “Наука",

14.Лайонз Дж. (1978) ,Экзистенцианльные, локативные и посессивные конструк-ции. В кн.: Введение в теоретическую лингвистику. Перевод с английского языка. Москва "Прогресс".

15. Мусаев О.И. (1961) Порядок слов в предложениях английского и азербай- джанского языков. Автореф.дисс. ... канд.филол.наук. Баку,.

16. Полтавцева Е.А.(1958) Предпосылки возникновения конструкции “There is” в древнеанглийском языке // Ленинградский государственный педаго-гической институт им. А.И.Герцена Ученые Записки. Том 157, Факультет английского языка,.

17. Русские бытийные глаголы и их субъекты. (1989),В кн.: Слово и грамматические законы языка. Глагол. Москва, "Наука",.

18.Янко Т.Е. (2000), Бытование и обладание: конструкции с глаголом “быть”. В кн.: Логический анализ языка: Языки пространств. Москва. 